\title{
SPATIAL PLANNING LEGISLATION IN GHANA: EXPLORING THE EVOLUTION, CONTRIBUTIONS, AND THE WAY FORWARD.
}

\author{
Sarfo, A. K. \\ Department of Planning, Kwame Nkrumah University of Science and Technology (KNUST) Kumasi, Ashanti Region \\ Corresponding Authors' Email: sarfoanthony38@yahoo.com
}

\begin{abstract}
This paper explored the evolution of spatial planning in Ghana's context. Using Institutional Analytical Framework, the paper posits that spatial planning has gone through several changes over the years. Additionally, it was revealed that spatial planning as an idea dates back to nineteenth-century industrialization and urbanization that mostly happened in developed countries. These had less focus on civic design and came to be more competent in state policy. Although planning in Ghana antedates the early 90s, nationwide spatial planning commenced with the preparation and initiation of CAP 84 (Town and Country Planning Ordinance) in 1945. Fast forward spatial planning in Ghana is presently being done by tenets and provisions as captured in Act 925 - Land Use and Spatial Planning Act 2016. However, this paper establishes possible conflict and duplication of planning efforts and practices by looking at Act 925 and Act 480 - National Development Planning System Act, 1994. It envisages that planning in Ghana will go through another evolution to avert the "spatial" and "policy" perspectives to planning and as well attain coordinated efforts to guide the course of planning in Ghana.
\end{abstract}

Keywords: Spatial planning, Land use, Evolution, Planning conflict

\section{Introduction}

In principle, spatial planning has come about due to evolution in nature, context, and the extent of planning. These changes and advancement is not peculiar to Ghana or Africa but transcends globally. For instance, for about two decades, spatial planning has gained prominence significantly in the European Union. Needham (2005) reveals that, in 2004 , tenets of spatial planning were made use of with the enactment of a spatial planning act to supersede erstwhile physical planning in Dutch planning legislation while in Britain. Spatial planning designates activities revolving around planning, urban planning, city and regional planning, and town and country planning (Taylor, 2010). The varying nature concerning these terms is assumed to have come about as a result of how writers captioned their books (See Taylor, 2010). For instance, books such as "Town and Country
Planning", "Urban Land Use Planning", Urban and Regional Planning", "Environmental Planning", are virtually describing the same issues and essentially a similar kind of planning (Keeble, 1952; Chapin, 1965; McLoughlin, 1969; Hall, 1974; Allison, 1975). From Acheampong (2018), the activities in planning are evolving over the years to suit prevailing contemporary environmental and socioeconomic challenges. Spatial planning has been acknowledged and known over the years by other associated expressions which include urban planning, physical planning, land use planning, regional planning, town and country planning, and simply planning. These show the changing nomenclature of spatial planning.

In several countries, spatial planning forms part of the governance systems which serve as a platform for articulation and implementation of government 
policies mostly designed to aid the achievement of an integrated and well-designed organization of activities (Owens \& Cowell, 2002). Many writers (e.g. Cullingworth \& Nadin, 2006; Korah, et al., 2017) also see spatial planning as a task for ensuring sustainable development and aids in achieving impartial distribution of gains from economic development between regions in a particular state (Allmendinger \& Haughton, 2009). Hedidor, et al. (2016) adds that spatial planning as a concept is a very imperative phenomenon geared towards safeguarding social, economic, and environmental harmony (See Table 1) in that, designing urban spaces improves the quality and sustainability of life even in warm climatic areas (Smith \& Levermore, 2008 as cited in Hedidor, et al., 2016).

This notwithstanding, nature, extent, and what spatial planning stands for is what regulations guiding it says it is. Thus, spatial planning is carried out in the remit of various regulations and tends to change whenever these regulations change. The frequency of change is mostly country-specific such that, regulations are susceptible to change due to changing country economic pathways (Adarkwa, 2012) and global dynamism such as the implementation of global policies like the Millennium Development Goals (MDGs) and Sustainable Development Goals (SDGs) (Korah et al., 2017; Acheampong, 2018; Chigudu \& Chirisa, 2020). A review of how spatial planning has changed in meaning, extent, and contribution to spatial development due to the changing nature of regulations is indispensable in making it better now and in the future.
Spatial planning in Ghana is not exempted from the various vicissitudes that spatial planning has taken over the years worldwide. Although Yeaboah (2002) and Owusu (2008) observed Ghana's planning systems as feeble and as well ineffectual in carrying out its objectives, Ghana was among countries in Africa, to have developed a Development Framework, national in scope and with spatial orientations (UN-Habitat, 2014). The seeming twists and turns in Ghana's planning systems may explain the country's weak implementation techniques and may influence the future course of planning. This paper is thus avid to examining the spatial planning evolution in Ghana from the 1990 s to date.

\section{Methodology}

It is duly acknowledged that literature posits less documentation on the subject under review. However, contemporary spatial planning has been established as a phenomenon that has gone through an evolution over the years. The focus is then to look into how and when spatial planning was given credence to, acknowledged, and imbued into the various development plans that have ever been prepared and implemented or plans that could not see the light of day. The chronology of events captured in this paper dates as far back as the 1990s where planning commenced and tenets of planning were used for the development of Ghana as reported by many writers (See Dickson, 1968; Adarkwa, 2012; Osei-Bonsu, 2012; Baffour Awuah, et al., 2014; Acheampong \& Ibrahim, 2016)

Table 1. Benefits of spatial planning

\begin{tabular}{|l|l|l|}
\hline Economic & Social & Environmental \\
\hline $\begin{array}{l}\text { Aids in the provision of a } \\
\text { stable economy that fosters } \\
\text { investor confidence. }\end{array}$ & $\begin{array}{l}\text { Incorporates in policy } \\
\text { development the aspirations } \\
\text { of the local communities }\end{array}$ & $\begin{array}{l}\text { Promotes appropriate use of land, } \\
\text { regeneration, and judicious use of } \\
\text { infrastructure and buildings }\end{array}$ \\
\hline
\end{tabular}




\begin{tabular}{|l|l|l|}
\hline $\begin{array}{l}\text { Identification of suitable } \\
\text { locations for cost-effective } \\
\text { development of land }\end{array}$ & $\begin{array}{l}\text { Improves upon social } \\
\text { accessibility concerning } \\
\text { where new development } \\
\text { will be carried out }\end{array}$ & $\begin{array}{l}\text { Promotes usage of both brownfield and } \\
\text { Greenfields }\end{array}$ \\
\hline $\begin{array}{l}\text { Ensures that land for } \\
\text { development is well-sited and } \\
\text { befitting the sort of } \\
\text { development }\end{array}$ & $\begin{array}{l}\text { Aids in the identification of } \\
\text { stressed areas and total lack } \\
\text { with regards to local } \\
\text { facilities }\end{array}$ & $\begin{array}{l}\text { Prevention of environmental pollution and } \\
\text { conservation of significant cultural and } \\
\text { historical assets }\end{array}$ \\
\hline $\begin{array}{l}\text { Promotes quality of the } \\
\text { environment in both rural and } \\
\text { urban areas }\end{array}$ & $\begin{array}{l}\text { Promotes the reuse of } \\
\text { rundown and vacant land with } \\
\text { economic development } \\
\text { potential and impact on the } \\
\text { quality of life }\end{array}$ & $\begin{array}{l}\text { Protects and enhances areas for recreation } \\
\text { and natural heritage. }\end{array}$ \\
\hline $\begin{array}{l}\text { Identification of various } \\
\text { development designed to } \\
\text { meet local community needs }\end{array}$ & $\begin{array}{l}\text { Promotes the creation and } \\
\text { effective maintenance of } \\
\text { healthy, safe, and pleasant } \\
\text { environments }\end{array}$ & $\begin{array}{l}\text { Encourages access to all modes of } \\
\text { transport }\end{array}$ \\
\hline $\begin{array}{l}\text { Promote regeneration and } \\
\text { renewal of economic value of } \\
\text { land assets }\end{array}$ & $\begin{array}{l}\text { Make decisions in a more } \\
\text { consistent and efficient way }\end{array}$ & $\begin{array}{l}\text { Incorporates tenets of efficiency in the use } \\
\text { of energy in the design and development } \\
\text { of plans }\end{array}$ \\
\hline
\end{tabular}

Source: Adapted from Hedidor, et al. (2016)

Literature was greatly reviewed for this paper as a secondary source of information. These sources were mainly reports, articles, periodic journals, news items, and books concerning planning in Ghana. Legislations that were assessed were CAP 84 - Town and Country Planning Ordinance of 1945, Act 480 - National Development Planning (System) Act of 1994, Act 925 - Land Use and Spatial Planning Act of 2016, Act 462 - Local Government Act of 1993, Act 479 - National Development Planning Commission Act of 1994, and Act 936 - Local Governance Act of 2016. These were reviewed with the interest of knowing the objectives behind the promulgation of each act and regulation, their contribution to planning in Ghana, and the lapses identified that led to their repeal and abolishment in certain cases.

\section{Evolution of Spatial Planning in Ghana}

Urban planning as an idea is conceived by various writers as a phenomenon of the $19^{\text {th }}$ century industrialization and urbanization that mostly happened in developed countries, had less focus on civic design and came to be more competent of state policy (Cobbinah \& Darkwah, 2017). Contextually, the discussion regarding the evolution of spatial planning in Ghana will be presented chronologically. The paper adopted a similar Institutional Analytical Framework to what ObengOdoom (2012) used when he was recounting and documenting Sekondi-Takoradi's growth over the years. The same analogy was as well used by Adarkwa (2012) in documenting the nature and extent of development in Ghana over the years and Acheampong (2018) in his book: "Spatial Planning in Ghana". In all, they postulated that historical happenings in Ghana can be presented under the aegis of four time periods. These identified eras are times before independence, independence, postindependence, and contemporary times. 


\section{Pre-independence Era}

Fuseini \& Kemp (2015) report that planning in Ghana started early twentieth century, thus, when the 1920-1930 plan of Guggisberg was executed under British colonial rule. Also, Acheampong (2018) reports on the implementation of Alan Burns' four - year development plan in the 1940s (from 1942 to1947). These dispensations saw planning done on the shoulders of European doctrines of planning. The sort of planning hovered around the identification and mapping of places for the implementation of major developments for the achievements of strategic objectives. Resulting from these plans was the improvement in sectors such as energy, transport, health, water, and sanitation as well as education. Although there may seem to be having some inherent spatial connotation, the sort of planning was not holistic. Adarkwa (2012) recounts that the plan implemented was beset with an economic motive for the exploitation of resources. Attention was given to areas where resources can be attained to the detriment of areas not endowed. The resultant effect is the least industrialized and urbanized state of the previous three administrative regions which consisted of Northern, Upper East, and Upper West regions and modern-day five administrative regions (Upper West, Upper East, Northeast, Savannah, and Northern regions) till this current time (Dickson, 1968). Osei-Bonsu (2012) added that the precolonial era, with the Guggisberg plan, among other benefits, brought about the basis for Ghana (then Gold Coast) becoming a major exporter of cocoa, gold, and timber globally during the colonial government (Songsore, 2010).

\section{Independence}

The 1940s saw the promulgation of the CAP 84 Town and Country Planning Ordinance. The CAP 84 marked the commencement of urban planning and preparation of plans nationwide (Cobbinah \& Darkwah, 2017; Acheampong, 2018). Spatial planning was carried out by enforcing zoning and building codes (Ahmed \& Dinye, 2011). However, these were done to maintain a European character (Grant \& Yankson, 2003 as cited in Adarkwa,
2012). Additionally, Acheampong (2018) noted that the ordinance and its accompanying planning system were "exported to Ghana" (pp. 56) which was a colony then. He again added that CAP 84 was part of new legislation made for planning activities that were introduced in Britain after World War II (periods around 1945 to 1952) to serve as a guide to the reconstruction programme after the war (Greed \& Johnson, 2014). The specific objective of the ordinance was "...to make provision for the orderly progressive development of land, towns, other areas, whether urban or rural, to preserve and improve the amenities thereof, and other matters, connected, therewith" (Town and Country Planning Ordinance (CAP 84)). Falling from this was the establishment of the first-ever planning BoardTown and Country Planning Board (The Board) - as the authority in charge of the town and country planning. The Board comprised the President (appointed by the minister), the Heads of Medical, Public Works and Lands Department, or representatives appointed by them respectively. Additionally, there were two - four other members appointed by the Minister (See Town and Country Planning Ordinance (CAP 84) section three (1\&2)). For the first time, a team of planners carried out planning tasks under British Town Planning Advisors after being given requisite training in Britain. Eventually, there was the abolishment of the Town and Country Planning Board with amendments such as the Act 30 - Town and Country Planning Act (1958) and Act 33 - Town and Country Planning (Amendment) Act (1960). Planning powers were therefore conferred on the Minister. This prevailed until the decentralization programme surfaced around 1993 (Acheampong, 2018). In sum, Acheampong (2018) reports that this era witnessed an overly centralized planning system. Planning was done piecemeal and was not collaborative since only a few areas were declared as planning areas at the behest of the Minister.

\section{Post-independence}

This era saw planning scaled up to national comprehensive planning. Such a nature of planning was deemed by the then government as a medium 
through which it could advance its socialist policies and as well implement the envisaged idea of building the cooperate and public sectors in the productive economy. The National Planning Commission in 1961 was commissioned to frame a plan for the national development and reconstruction agenda - the Seven-Year Development Plan (1964-1970). This plan was the second National Perspective/Plan following the implementation of the first National Perspective plan during periods between 1951 and 1956. Subsequently, 1963-1970 saw the preparation of the first comprehensive spatial plan-National Physical Plan- by the Town and Country Planning Division. Among other tenets, the plan aimed at advancing a modern agenda, thus, to create a society where people will gain the ability to have modern living standards in their homes which are augmented by having access to cutting-edge public service levels outside their homes (1963/64-1969/70 Seven-year Development Plan). Specifically, the aim of the National Physical Development Plan of 1963-1970 was to:

- Give a guide to the annual phasing and budgeting of the seven-year investment programme;

- Propose solutions to the problems with locations in connection with all investment projects taking place from 1963 to 1970 ;

- Give a guide to investment assumption for perspective plan preparation;

- Guide the advancement of various regional development plans;

- Give guidance to the advancement and preparation of local development plans for urban settlements as well as cities; and

- Facilitate practical system(s) of survey and analysis formation.

The National Physical Development Plan (19631970) as a coast-to-coast comprehensive plan served as a basis for the design and implementation of successions of lower-level plans. These plans were referred to as Master Plans and they were to help in translating visions into action as embedded in the National Physical Development Plan and to spell out the way for the subsequent future growth of settlements in Ghana -towns, and cities- mostly the major ones. Falling from this is the preparation of a statutory Accra Master plan, titled "Accra: A Plan for the Town" and promulgated in 1958. The preparation of the Master Plan for Kumasi followed that of Tema in 1963 to guide the development of Kumasi. The plan was to preserve the Golden City character (See Korboe, 2001) the then Kumasi had through tenets of land use regulation and development control. This may be of a central planning system with less participation until the post-independence era where institutional capacity is strengthened and spatial planning coverage was broadened which led to instituting various departments solely for planning across the country.

\section{Contemporary Era}

Regrettably, the seeming successes chalked with regards to spatial planning and planning as a whole was hit with challenges from 1966. This era saw the overthrow of Dr. Kwame Nkrumah as the country experienced military takeovers. Implementation of these landmarked master plans was curtailed with the political turmoil and frequent changes in government in the late 1960 s to early 1980 s. Although there were short term plans made during these perilous times, the overall achievement with regards to spatial planning was minimal at the local level (Acheampong, 2018). Consequently, importance was given to participation at the local level in the development process as part of the reforms that were brought up during the late 1980s. Such commitment to local level development was shown with the preparation and promulgation of PNDC Law 207. This was the first major legislation concerning decentralization (transferring decision making powers to local government) and it raised District Assemblies from initially 45 to 65 as of 1992 (IMANI Africa, 2018). Further strengthening of decentralization was the promulgation of Act 462-Local Government Act, 1993 to take the place of the Provisional National Defense Council Law 207. This heightened the mandates of District 
Assemblies to ensure the inclusive development and growth of areas under local governance. Additional to Act 462 was the promulgation of Act 480 National Development Planning System Act, 1994 to make available a legal basis for planning in Ghana at all levels. However, the regional and national levels of political administration witnessed neglect of spatial planning. Quintessentially, the nature of planning at that time was basically development planning, concentrating on policy to the neglect of spatial allocations and the issues thereof. Ghana had been operating a traditional level development planning as the Act 480 - National Development Planning System Act - posits. There was the establishment of the Development Planning Unit (DPU) that was in charge of development Planning (limiting its scope to taking steps in addressing socio-economic issues - poverty alleviation. Town and Country Planning that was in charge of land use planning -layouts preparation for neighborhoods, cities, and towns, with recourse to control of development (Acheampong \& Ibrahim, 2016).

Successive governments have formulated various medium-term national frameworks with Growth and Poverty Reduction Strategy [GPRS 1 and II from 2003 to 2008] and the Ghana Shared Growth and Development Agenda (GSGDA I and GSGDA II implemented in 2010-2013 and 2014-2017 respectively). These implemented National Policy Frameworks hinged on restructuring social as well as economic issues, poverty reduction, and macroeconomic stability. Historically, various National Policy frameworks in their implementation lacked consideration of the spatial manifestations in the planning and management of human settlement. From this perspective, Acheampong \& Ibrahim (2016) further recount weak policy assimilation between the local level spatial and socioeconomic planning within the existing tradition of development planning. This is on grounds that, there are two distinct decentralized planning entities at the various MMDAs almost always working in isolation: District Planning Unit is mandated to carry out the preparation of Medium Term Development Plans whereas Town and Country Planning is concerned with development control and land allocation.

From the Land Administrative Project - LAP I - in 2003 was the Land Use Planning and Management Project (LUPMP) rolled out in 2007. The objective of the LUPMP was the development of a decentralized land use management and planning system, coherent and rooted in participatory and consultative approaches to effectively manage human settlements. Emanating from this project were several developments. Four pronounced developments are:

- Preparation and promulgation of Act 925 Land Use and Spatial Planning Act, 2016;

- Reorganization of spatial planning and institutional arrangements that led to the institution of Land Use and Spatial Planning Authority;

- The three-tier system of planning institutionalization;

- Land Use and Spatial Development Fund established. 
Table 2 Summary of a series of landmark events in Ghana with regards to Development Control and Spatial Planning.

\begin{tabular}{|c|c|c|}
\hline Year & Event & Objectives and contributions \\
\hline 2018 & Promulgation of National Building Codes & $\begin{array}{l}\text { 1. Provide developers, investors, and building } \\
\text { professionals, with common standards for safety, public } \\
\text { health, structural efficiency, environmental integrity, } \\
\text { and fire protection. } \\
\text { 2. take center stage in ensuring standardization in the } \\
\text { construction industry }\end{array}$ \\
\hline 2016 & $\begin{array}{l}\text { Promulgation of Act } 925 \text { - Land Use and } \\
\text { Spatial Planning Act }\end{array}$ & $\begin{array}{l}\text { 1. Revision and consolidation of various land use } \\
\text { planning laws } \\
\text { 2. make provisions for sustainable land development } \\
\text { and human settlements through a decentralized system } \\
\text { of planning } \\
\text { 3. promotion of health and safety concerning human } \\
\text { settlements } \\
\text { 4. improve the quality of life by ensuring judicious use } \\
\text { of land } \\
\text { 5. Regulation of spatial planning at the national, } \\
\text { regional, district, and local levels } \\
\text { 6. provide for spatial aspects of socio-economic } \\
\text { development and related matters. }\end{array}$ \\
\hline 2013 & $\begin{array}{l}\text { Formulation of the Greater Kumasi Sub- } \\
\text { Region Spatial Development Framework }\end{array}$ & $\begin{array}{l}\text { Fashioned to guide the contemporary development of } \\
\text { Kumasi Metropolis and other seven adjoining Districts. }\end{array}$ \\
\hline 2012 & $\begin{array}{l}\text { Formulation of National Urban Policy } \\
\text { Framework }\end{array}$ & $\begin{array}{l}\text { Objected to aid the promotion of sustainable, orderly } \\
\text { developed, and spatially integrated settlements in urban } \\
\text { areas. This development should be with efficient } \\
\text { institutions, infrastructure, and services adequate } \\
\text { housing, and a sound living and working environment } \\
\text { for all persons to support the fast socio-economic } \\
\text { development of Ghana. }\end{array}$ \\
\hline 2010 & $\begin{array}{l}\text { Land Use Planning and Management Project } \\
\text { (LUPMP) }\end{array}$ & $\begin{array}{l}\text { Established to tackle frail land-use planning systems at } \\
\text { all levels. Implemented for three years under the land } \\
\text { Administration Project. }\end{array}$ \\
\hline 1994 & $\begin{array}{l}\text { Promulgation of Act } 480 \text { - National } \\
\text { Development Planning (System) Act }\end{array}$ & $\begin{array}{l}\text { Contributed to spatial planning and its education in } \\
\text { Ghana. Established various department (DPUs) } \\
\text { decentralized to convert national goals prepared by the } \\
\text { NDPC into local Medium Term Development Plans. }\end{array}$ \\
\hline 1993 & $\begin{array}{l}\text { Promulgation of Act } 462 \text { - Local } \\
\text { Government Act }\end{array}$ & $\begin{array}{l}\text { Replaced PNDC Law } 207 \text { and passed on considerable } \\
\text { powers of administration to the various district } \\
\text { assemblies at the local level and gave them } \\
\text { competencies to guarantee the holistic growth of the } \\
\text { various areas of local government. }\end{array}$ \\
\hline
\end{tabular}




\begin{tabular}{|c|c|c|}
\hline 1988 & PNDC Law 207 & $\begin{array}{l}\text { Fostered decentralization and aided the reformation of } \\
\text { the existing structure of governance in Ghana and } \\
\text { increased participation at the local level in the } \\
\text { development process. }\end{array}$ \\
\hline 1963 & $\begin{array}{l}\text { Planning Scheme for Kumasi Metropolis } \\
\text { prepared }\end{array}$ & $\begin{array}{l}\text { Fashioned to give guidance to the development of } \\
\text { Kumasi with the provision of broad land use zones with } \\
\text { provisions for residential, industrial, and commercial } \\
\text { areas. It came to be a primary document for the } \\
\text { regulation of land use and development control. }\end{array}$ \\
\hline 1963 & Seven-Year National Development Plan & $\begin{array}{l}\text { A comprehensive approach by which the then } \\
\text { government articulated its social policies and aided in } \\
\text { building the cooperate and public sectors in a } \\
\text { productive economy that will make individual } \\
\text { Ghanaian relish a modern standard of living at home. }\end{array}$ \\
\hline 1961 & Tema Master Plan & $\begin{array}{l}\text { To guide future development of the town which was } \\
\text { deemed as a major industrial hub under the national } \\
\text { infrastructure development and industrialization } \\
\text { policies }\end{array}$ \\
\hline 1958 & $\begin{array}{l}\text { Establishment of Planning programme at } \\
\text { Kwame Nkrumah University of Science and } \\
\text { Technology (KNUST) }\end{array}$ & $\begin{array}{l}\text { Introduction of planning programmes and curricular } \\
\text { fashioned to train professionals to man newly } \\
\text { established District Planning Units at MMDAs level } \\
\text { and other institutions at the national (NDPC) and } \\
\text { regional levels. }\end{array}$ \\
\hline 1958 & Accra Master Plan & $\begin{array}{l}\text { One of the city level instruments prepared as a major } \\
\text { plan to harness that of } 1944 \text { and to improve the existing } \\
\text { circumstances and as well proposes that future } \\
\text { development is carried out in such a manner that fits a } \\
\text { capital city. It was also to be economically and } \\
\text { practically feasible }\end{array}$ \\
\hline 1951 & Five-Year National Development Plan & $\begin{array}{l}\text { Fashioned to foster Social and Economic Development } \\
\text { of Ghana (the then Gold Coast) till } 1956\end{array}$ \\
\hline 1945 & $\begin{array}{l}\text { Town and Country Planning Ordinance } \\
\text { (CAP 84) promulgated }\end{array}$ & $\begin{array}{l}\text { 1. To provide for the orderly and progressive } \\
\text { development of towns and land. } \\
\text { 2. To aid the preservation and improvement of services } \\
\text { in such developing areas. }\end{array}$ \\
\hline 1942 & $\begin{array}{l}\text { National Four-Year Development Plan of } \\
\text { Alan Burns }\end{array}$ & \multirow{2}{*}{$\begin{array}{l}\text { 1. To develop infrastructure and services. } \\
\text { 2. Identifying and mapping target areas for } \\
\text { development of hydroelectric projects, improvement in } \\
\text { transportation infrastructure, public services delivery } \\
\text { such as sanitation, water, hospitals, and schools } \\
\text { 3. housing development schemes to foster the } \\
\text { improvement of towns }\end{array}$} \\
\hline 1919 & 10-Year Development Plan of Guggisberg & \\
\hline
\end{tabular}

Source: Authors construct, 2020 


\section{Comparison of the two contemporary planning regulations}

Before the inception of Act 925 - Land Use and Spatial Planning Act, 2016, tenets of the Town and Country Planning Ordinance (CAP 84) was employed to guide development control and land use planning for about 70years, however foreign it was or obsolete it became at some point in time. The Ordinance objected to providing for the progressive and orderly land development, be it urban or rural, and for the improvement and preservation of the facilities of such areas where development is taking place. The obsolete nature of the ordinance (CAP 84) necessitated the promulgation of the new act with seemingly replete provisions required to tackle land-use planning in the contemporary era. The purposes of the new spatial planning act - Act 925 Land Use and Spatial Planning Act, 2016 was to make provisions for

1. the revision and consolidation of various land use planning laws

2. sustainable land and human settlements development through a decentralized system of planning

3. the promotion of health and safety with respect to human settlements

4. improvement of quality of life by ensuring judicious use of land

5. regulation of national, regional, district, and local spatial planning

6. provision for spatial aspects of socioeconomic development and related matters (Land use and Spatial Planning Act, Act 925, 2016).

Act 925 acknowledges that socioeconomic interventions have spatial connotations and for that matter, efforts should be put in place to diktat the implication of such intervention on land. The reforms the new law proposes are profound and can be discussed under three focus areas. These are the declaration of planning areas, the Institutional framework for the administration of planning and nature, and levels of planning. The subsequent section juxtaposes Act 925 and the Town and Country Planning Ordinance CAP 84.
Declaration of planning areas

Per section 9 (1, 2, $3 \& 4$ ), of CAP 84, a planning area is declared at the prerogative of a Town and Country Planning Board constituted and chaired by a president appointed by the Minister (section 3). Consequently, the value of any parcel of land or building in such an area shall, to determine the amount of compensation or betterment that will be paid under the provisions of this ordinance, be considered to be the value of the building on the day (twelve months) immediately before such declaration or in the case of a building erected after such day but before the date on which the area was declared a Planning Area, the value of the building at the time of its completion (section 9(4)). Section $10(1,2)$ prohibits any form of development and the accompanying punishment for defaulters thereof. From this, planning was done in a piecemeal approach. The new planning legislation proposes a comprehensive method to replace this approach. Act 925, per section 45, pronounces all areas in Ghana as areas earmarked for planning. The boundaries of Ghana is subject to the provision made in the Article 4(1,2) of chapter two of the 1992 Republic of Ghana's constitution in that, the landmass, air space, sub-terrain territory, marine space, and reclaimed lands shall be planning areas and is subject to the various planning systems provided under the Land Use and Spatial Planning Act, Act 925 and other relevant laws that bother with spatial planning.

Institutional framework for the administration of planning.

Over the decades, planning was in the hands of various sectorial boards and concentrated on socioeconomic perspectives and poverty alleviation. The CAP 84, giving credence to spatial planning, established the Town and Country Planning Board (Section 3). Through reforms that contributed to decentralization and acts such as Act 462 - Local Government Act, the Board was changed to a Department - TCPD - under the local government structure and aided the establishment of such offices nationwide and were given the mandate 
for planning (spatial) in Ghana. Act 925 at large maintained the national, regional, and district levels of decentralization. The Land Use and Spatial Planning Act, 925, establishes, at the national level, the Land Use and Spatial Planning Authority. The existing regional level was replaced with Regional Spatial Planning Committee while spatial planning at the local and district level is presently in the hands of the Physical Planning Department, initially Town and Country Planning Department. The new Act 925 proposes comprehensive onuses for all the levels of planning and fosters the integration of concepts of spatial planning in the preparation of Development - Socio-Cultural and poverty alleviation - Plans. Based on these provisions: sections $48,52,57$, there should be the preparation of the National Spatial Development Framework, Regional Spatial Development Framework, and the
District Spatial Development Framework from which structure plans and local plans are prepared (Sections 48, 52, 57 of Act 925). Aside from these, there is the sub-Regional Spatial Development Framework for Kumasi and its environs (MESTI 2011 as cited in Acheampong \& Ibrahim, 2016). The Model Guidelines for national spatial planning system takes into consideration intergovernmental integration and decentralized spatial planning at the various levels of spatial development. The Guidelines defines Spatial Development Frameworks as '......... an indicative plan, showing the expected development over a fifteen to twentyyear period, which will include the location of key components of the strategy aimed at achieving the desired development' (MESTI, NSPS Module Guideline 2011: p.9 as cited in Acheampong \& Ibrahim, 2016).

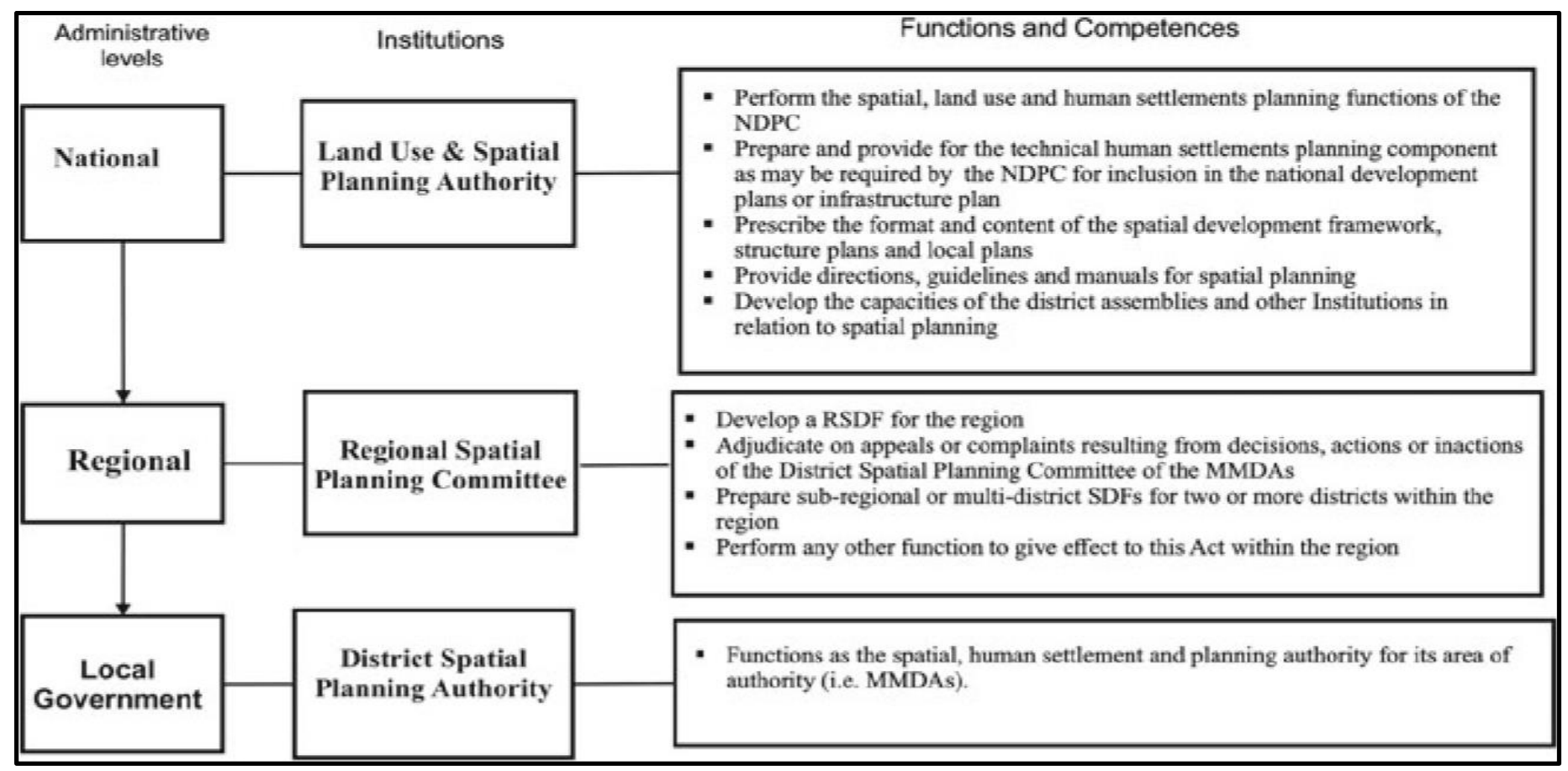

Figure 1: Levels of planning and responsibilities as proposes in Act 925 - Land Use and Spatial Planning Act. Adapted from Acheampong (2018). 


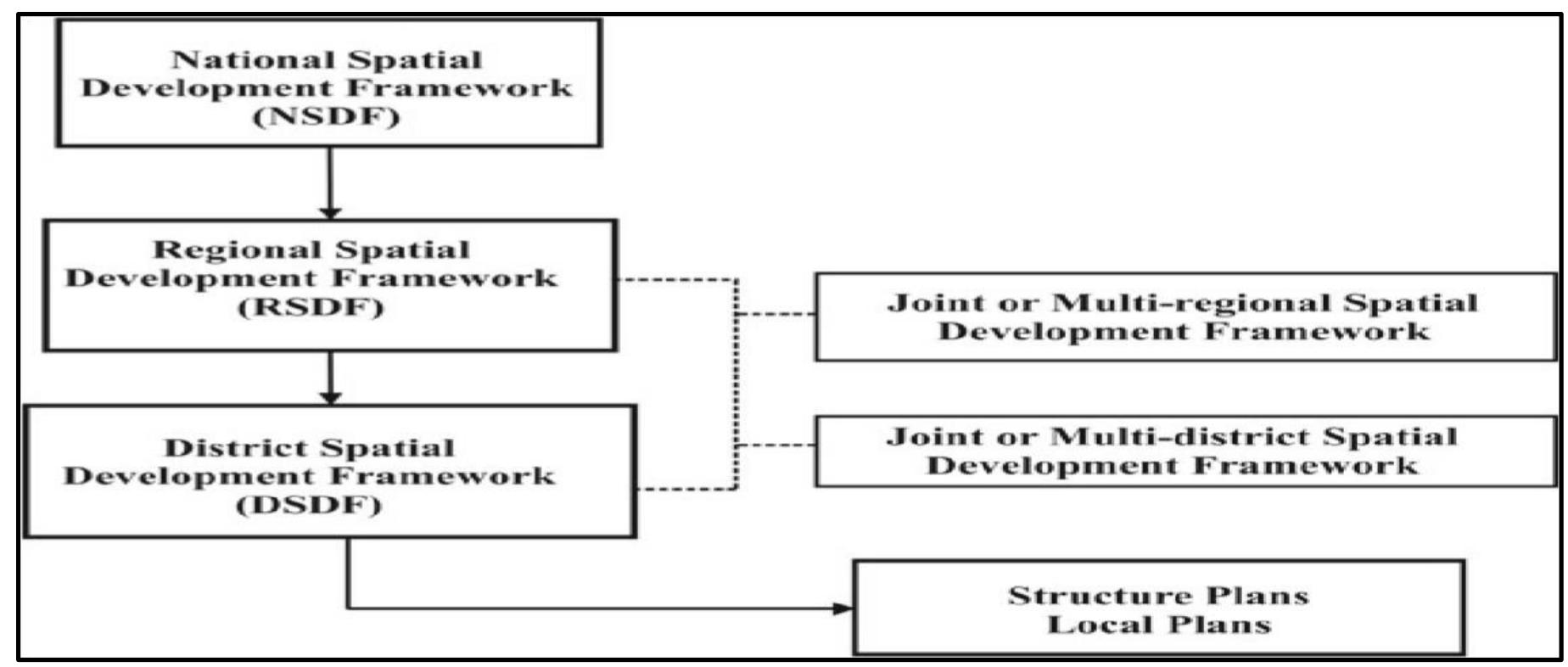

Figure 2: Workflow and series of spatial plans to be made as to the Act 925 Land Use and Spatial Planning Act, 2016 proposes. Adapted from Acheampong (2018).

\section{Challenges of Ghana's Spatial Planning}

Botchie (2000)recounts that there have been attempts by governments geared towards the improvement of the livelihood of people living in Ghana. This was done during the early years of the country's development through various development plans. Regrettably, these development plans among others suffered protracted periods of birth pangs and became antediluvian even before their implementation period elapsed (Botchie, 1986). For instance, the Town and Country Planning Department contributed to a formulation of a consolidated Seven Year National Development Plan in the 1960 s by preparing the National Development Framework which never saw the light of day. Attributable, there is a lack of continuity of development programmes by national governments mostly due to frequent changes in government over the years. Botchie (2000) reports that human settlement planning was an underpinning factor that necessitated the establishment of the Town and Country Planning Department. From that time, spatial planning was given attention. The Department “.... is however unstable and ill-equipped to perform its function"

Sarfo., 2020: UDSIJD Vol 7(2)

DOI:
(Botchie 2000: pp8). Such instability has been identified as a contributive factor to the Department's unsatisfactory performance in that, the department, at varying times, has been placed under eighteen different ministries (Citifmonline, 2015). In 2016, the Department came under the Ministry of Environment, Science, Technology, and Innovation (MESTI) and presently under the Planning Ministry. This movement of the department from ministry to ministry disturbs the focus since each minister may come with a varied focal point regarding the country's spatial planning (Citifmonline, 2015).

Yeboah \& Obeng-Odoom (2010) also added that in all indicators, planning has failed to wield effective influence on the growth of human settlement in Ghana. In a work done on the perspectives of District Assemblies on the state of planning in Ghana, they pointed out five hitches and setbacks regarding planning as a spatial activity, thus, undue political interference in the planning; weak human resources capacity; weak land tenure systems; weak legislative framework; and inadequate funding. 
Additionally, Cobbinah \& Darkwah (2017) recount that planning in Ghana is mired by political connotations. They advanced the argument that, the incessant hitches on effective urban planning are seemingly faraway beyond the possible reach of agencies in charge of planning especially in Ghana. Agreeing to Cobbinah, et al. (2015), Njoh (2003) and Cobbinah \& Darkwah (2017) stated that the approach to planning adopted by planning agencies is mostly characterized by simply moving from opinion to opinion, policies to policies which in a sense have no sanguine, sustainable and realistic approach to cohere to. Additionally, the conventional urban planning systems and practices made use of in Africa by planning agencies are often not based on principles such as pro-poor, inclusiveness, and equity (Watson \& Agbola, 2013). This to a large extent, has contributed to planning not being able to avert the problems that thwart the development of urban areas in Africa (Amoako \& Cobbinah, 2011; Cobbinah, et al., 2015; Cobbinah \& Darkwah, 2017).

\section{Conclusion}

The paper has demonstrated the changes and evolution of nature and the extent of planning in Ghana from the early 90s till the present day. From the discussions, it is evident that Ghana has had its share of the evolution of planning as it has been in other African countries and the entire globe at large. Several interventions have been made with the promulgation of various Acts over the years. Some plans were made to guide development with a focus on socioeconomic and poverty alleviation. Notable among them were the 10-year development plan of Guggisberg in 1919 and the four-year plan of Alan Burns in 1942. Formal spatial planning however commenced with the establishment of the Town and Country Planning Department by the CAP 84 Town and Country Planning Ordinance, 1945. It was during independence that building codes and zoning practices with European character as a means to order spatial development were enforced. CAP 84 was part of new legislation for planning that was introduced in Britain from 1945 to 1952 (after World War II) to give guidance to the programme geared towards post-war reconstruction (Greed \& Johnson, 2014). Under the era of independence, there was a highly centralized planning system since the declaration of areas as planning areas and approval of plans before implementation was at the behest of the Minister. Hence, planning was done piecemeal and was not comprehensive since a few areas (around the coast and resource endowed areas) benefitted from the planned environment and developmental programmes. Subsequently, the post-independence era witnessed spatial planning scaled up to the national level. The National Planning Commission in 1961 was commissioned to formulate the Development plan (Seven-Year) for national development and reconstruction (19641970). This plan was the second National Perspective/Plan following the implementation of the first National Perspective plan during 1951 and 1956. Subsequently, 1963-1970 saw the preparation of the first comprehensive spatial plan-National Physical Plan- formulated by the Town and Country Planning Division. Notable sub plans were Master Plans of Accra, Tema and Kumasi prepared in 1958, 1961, and 1963 respectively.

PNDC Law 207 was promulgated as an effort towards contemporary planning. This was the first major legislation concerning decentralization (transferring decision making powers to local government) and raised District Assemblies to 65 . Strengthening decentralization was the promulgation of Act 462 - Local Government Act, 1993 to replace the PNDC Law 207. This heightened the mandates of District Assemblies to ensure the holistic growth and development of areas of local governance. Additional to Act 462 was the promulgation of the National Development Planning System Act (Act 480) in 1994 to provide legal planning basis at all levels in Ghana. Frameworks such as the Growth and Poverty Reduction Strategy (GPRS) I and II as well as Ghana Shared Growth (GSGDA) I and II were all done in this era. Once more, Land Use and Management Project (LUPMP) came from the Land Administration Project (LAP I and II). The Land Use and Spatial Planning Act, Act 925 was 
promulgated in 2016. More presently is the promulgation of the National Building Codes to provide developers, investors, and building professionals, with common standards for safety, public health, structural efficiency, environmental integrity, and fire protection. Also, it is fashioned to take center stage in ensuring standardization in the construction industry. Apparently, the spatial planning spectrum has gradually changed over the years until the present day through several interventions.

Regardless of these interventions, spatial planning in Ghana is still stalled with challenges. These challenges include interference: both political and traditional, technical know-how, and ambiguities resulting from two Acts virtually talking about the same thing; plan preparations and implementation and overall planning in Ghana. Specifically, these are the National Development Planning System Act, 1994(Act 480), and the recent Land Use Spatial Planning Act, 2016 (Act 925). More explicitly, the National Development Planning System Act is bent on socio-economic transformation chiefly geared towards poverty reduction at two levels, thus, local level - Medium Term Deployment Plans which has a 4-year timeframe and national level - Medium Term development frameworks. The Land Use and Spatial Planning Act as well proposes a different three-tier hierarchy of power as entities that also carry out spatial planning. There is still less integration and coordination for holistic planning and its practices which is leading to duplication of efforts and planning activities which is resulting in a waste of resources to get things done under these two planning systems.

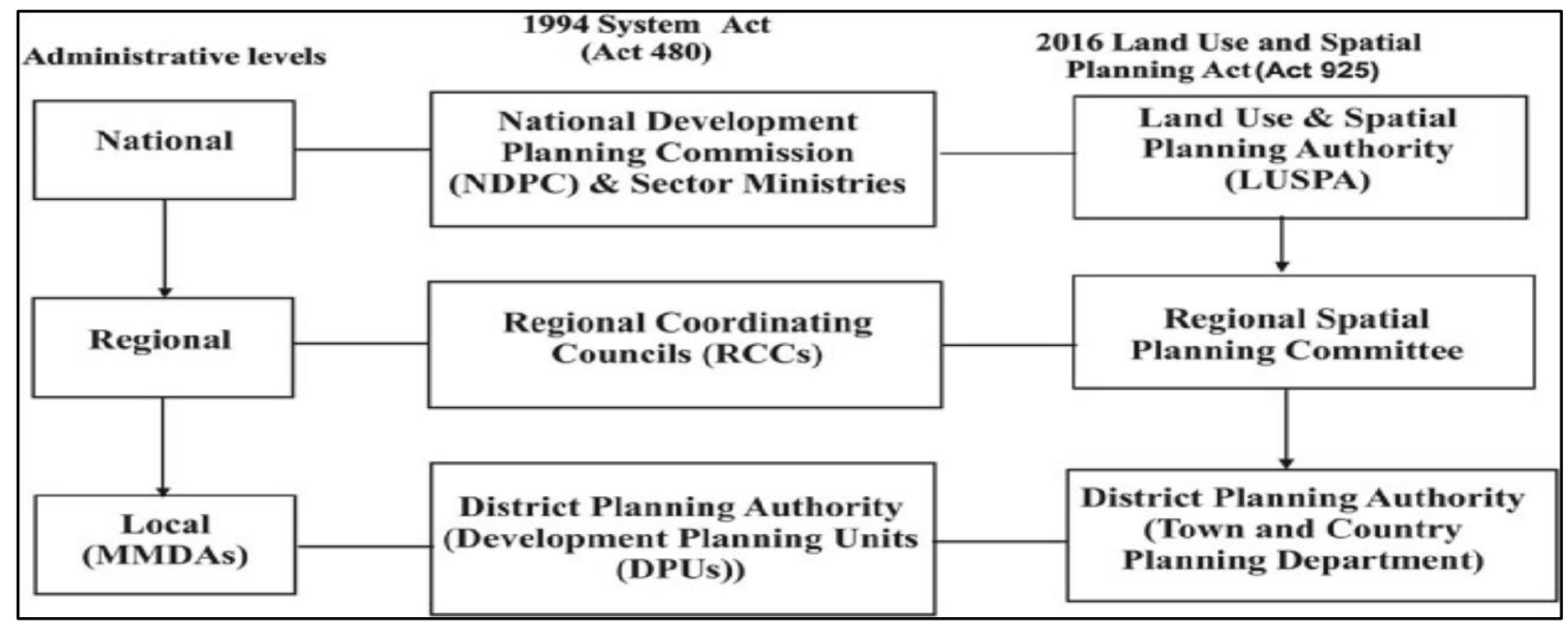

Figure 3: A comparison of the hierarchy as given by the two planning systems in Ghana: Act 925 and Act 480 - National Development Planning (System) Act. Adopted from Acheampong (2018).

Planning in Ghana although has gone through several advancements, is likely to go through other developments to achieve a cogent and enhanced pathway for the implementation of planning tenets in Ghana. This will also correct the loopholes and various lapses in the planning Acts being used presently. It is recommended that, for planning to thrive in Ghana, it should be done in a participatory manner and carried out within the ambit of the societal norms and aspirations. Spatial planning 
should be fashioned replete of tenets situated in the Ghanaian context and should encourage and have a place for civic initiative and self-governance.

\section{References}

Acheampong, R. A. (2018). Spatial Planning in Ghana (1st ed.). Springer International Publishing. https://doi.org/10.1007/978-3030-02011-8

Acheampong, R. A., \& Ibrahim, A. (2016). One Nation, Two Planning Systems? Spatial Planning and Multi-Level Policy Integration in Ghana: Mechanisms, Challenges and the Way Forward. Urban Forum, 27(1), 1-18. https://doi.org/10.1007/s12132-015-9269-1

Adarkwa, Kwasi Kwafo. (2012). The changing face of Ghanaian towns. Africa Review of Economics and Finance., 4(1): 1-29.

Ahmed, A., \& Dinye, R. (2011). Urbanisation and the challenges of development controls in Ghana: A case study of Wa Township. Journal of Sustainable Development in Africa, 13(7): 210-235.

Allison, L. (1975). Environmental Planning: A Political and Philosophical Analysis. Allen \& Unwin.

Allmendinger, P., \& Haughton, G. (2009). Critical reflections on spatial planning. Environment and Planning A, 41(11): 2544-2549. https://doi.org/10.1068/a42227

Amoako, C., \& Cobbinah, P. B. (2011). Slum improvement in the Kumasi metropolis, Ghana - a review of approaches and results. Journal of Sustainable Development in Africa, 13(8): 150-170.

Baffour Awuah, K. G., Hammond, F. N., Lamond, J. E., \& Booth, C. (2014). Benefits of urban land use planning in Ghana. Geoforum, 51: 37-46. https://doi.org/10.1016/j.geoforum.2013.09.01 9

Botchie, G. (1986). Planning and implementation of development plans in Ghana: an appraisal (C. K. Brown (ed.)). Ghana Universities Press. https://agris.fao.org/agris-

search/search.do?recordID=US201301408369

Botchie, G. (2000). Local Strategic Planning and Sustainable Rural Livelihoods. Environmental Planning Issues, 21, 83.

Chapin, F. S. (1965). Urban Land Use Planning (2nd ed.). University of Illinois.

Chigudu, A., \& Chirisa, I. (2020). The quest for a sustainable spatial planning framework in Zimbabwe and Zambia. Land Use Policy, 92. https://doi.org/10.1016/j.landusepol.2019.104 442

Citifmonline. (2015). Stop moving us around Town and Country Planning. Citifmonline.Com.

http://citifmonline.com/2015/02/02/stopmoving-us-around-town-country-planning/

Cobbinah, P. B., \& Darkwah, R. M. (2017). Urban planning and politics in Ghana. GeoJournal, 82(6),

1229-1245. https://doi.org/10.1007/s10708-016-9750-y

Cobbinah, P. B., Erdiaw-Kwasie, M. O., \& Amoateng, P. (2015). Africa's urbanisation: Implications for sustainable development. Cities, 47: 62-72. https://doi.org/10.1016/j.cities.2015.03.013

Cullingworth, B., \& Nadin, V. (2006). Town and Country Planning in the UK (14th ed.). https://www.amazon.com/Town-Country-

Planning-Barry-Cullingworth-dp-

0415358108/dp/0415358108/ref=mt_other?_e ncoding $=\mathrm{UTF} 8 \& \mathrm{me}=\&$ qid $=$

Dickson, K. B. (1968). Background to the problem of Economic Development In Northern Ghana. Annals of the Association of American Geographers, 58(4), 686-696. https://doi.org/10.1111/j.14678306.1968.tb01662.x

Fuseini, I., \& Kemp, J. (2015). A review of spatial planning in Ghana's socio-economic development trajectory: A sustainable development perspective. Land Use Policy, 47, 309-320. https://doi.org/10.1016/j.landusepol.2015.04.0 20 
Grant, R., \& Yankson, P. (2003). Accra. Cities, 20(1): 65-74. https://doi.org/10.1016/S02642751(02)00090-2

Greed, C., \& Johnson, D. (2014). Planning in the UK:An introduction. Palgrave Macmillan.

Hall, P. (1974). Urban and Regional Planning. Harmondsworth.

Hedidor, D., Bondinuba, F. K., \& Sadique, M. A. (2016). Spatial Planning in Ghana: Antecedents and the Role of Local Artisans. Journal of Building Construction and Planning Research, 04(03), 201-218. https://doi.org/10.4236/jbcpr.2016.43013

IMANI Africa. (2018). IMANI calls for transparency in the creation of new districts. GhanaWeb.

https://www.ghanaweb.com/GhanaHomePage /NewsArchive/IMANI-calls-for-transparencyin-creation-of-new-districts-656324

Keeble, L. B. (1952). Principles and Practice of Town and County Planning. The Estates Gazette.

Korah, P. I., Cobbinah, P. B., Nunbogu, A. M., \& Gyogluu, S. (2017). Spatial plans and urban development trajectory in kumasi, Ghana. GeoJournal, 82(6): 1113-1134. https://doi.org/10.1007/s10708-016-9731-1

Korboe, D. (2001). Historical development and present structure of Kumasi. In K. K. Adarkwa (Ed.), The fate of the tree (pp. 41-58). Woeli Publishing Services.

Land Use and Spatial Planning Act (2016). Land Use and Spatial Planning Act. Government of Ghana. Accra

McLoughlin, J. B. (1969). Urban and Regional Planning: A Systems Approach. Feber \& Feber.

Needham, B. (2005). The new Dutch spatial planning act: Continuity and change in the way in which the Dutch regulate the practice of spatial planning. Planning Practice and Research, 20(3), 327-340. https://doi.org/10.1080/02697450600568662

Njoh, A. (2003). Planning in contemporary Africa the State, Town Planning, and Society in
Cameroon. Ashgate.

Obeng-Odoom, F. (2012). Political economic origins of Sekondi-Takoradi, West Africa's new oil city. Urbani Izziv, 23(2), 121-130. https://doi.org/10.5379/urbani-izziv-en-201223-02-005

Osei-Bonsu, K. (2012). Structural Transformation of Ghana's Economy - The Role of Long-Term Development Planning. GhanaWeb. https://www.ghanaweb.com/GhanaHomePage /features/Structural-Transformation-Of-

Ghana-s-Economy-234320

Owens, S., \& Cowell, R. (2002). Land and limits: interpreting sustainability in the planning process. Land Use Policy, 19(4), 333-334. https://doi.org/10.1016/S0264-

8377(02)00043-1

Owusu, G. (2008). Indigenes' and migrants' access to land in peri-urban areas of Accra, Ghana. International Development Planning Review, 30(2): 177-198. https://doi.org/10.3828/idpr.30.2.5

Smith, C., \& Levermore, G. (2008). Designing urban spaces and buildings to improve sustainability and quality of life in a warmer world. Energy Policy, 36(12): 4558-4562. https://doi.org/10.1016/j.enpol.2008.09.011

Songsore, J. (2010). The urban transition in ghana: urbanization, national development and inequality.

http://pubs.iied.org/pdfs/G02540.pdf on 04/06/12

Taylor, N. (2010). What is this thing called spatial planning?: An analysis of the British Government's view. Town Planning Review, $81(2)$, 193-208. https://doi.org/10.3828/tpr.2009.26

UN-HABITAT. (2014). The State of African cities 2014: Re-imagining sustainable urban transitions.

Watson, V., \& Agbola, B. (2013). Who will plan Africa's cities? Africa Research Institute, Understanding Africa Today. https://www.africaresearchinstitute.org/newsit e/publications/who-will-plan-africas-cities/ 
Yeboah, E., \& Obeng-Odoom, F. (2010). 'We are not the only ones to blame': District Assemblies' Perspectives on the state of planning in Ghana. Commonwealth Journal of Local Governance, 7, 78-98. https://doi.org/10.5130/cjlg.v0i7.1893

Yeboah, I. E. (2002). Demographic and housing aspects of structural adjustment and emerging urban form in Accra, Ghana (pp. 107-119). Africa Today. 